\title{
Judicial Independence in the Democratic Republic of Congo: Myth or Reality?
}

\author{
Roger-Claude Liwanga*
}

\begin{abstract}
Soon after the first democratic elections were organized in 2006, the Democratic Republic of Congo engaged in a series of juridical reforms to ensure that the judiciary is free from interference from the other branches of government: the legislature and the executive. Accordingly, Law No 06/020 of 2006 on the Status of Magistrates and Law No 08/013 of 2008 on the Organization and Functioning of the Supreme Council of the Judiciary were enacted. This article examines judicial independence in the Democratic Republic of Congo today, and assesses the impact of the newly adopted legislation by comparing it with the preceding statutory provisions on the functioning of the judiciary. Do the laws on the status of magistrates and on the organization and functioning of the supreme council of the judiciary, as recently enacted, effectively strengthen the independence of the judiciary?
\end{abstract}

\section{INTRODUCTION}

Judicial independence is a thermometer to measure the "temperature" of democracy within a civilized society. It is a corollary of the doctrine of separation of powers between the branches of government: the legislature, executive and judiciary. Judicial independence refers to the right and duty of judicial officers to apply their own integrity to the execution of judicial functions, without being directly or indirectly influenced by other institutions or persons. ${ }^{1}$ Yet, the independence of the judiciary is also considered fundamental for safeguarding human rights, ${ }^{2}$ because judges are "charged with the crucial decision over life, freedoms, rights, duties and property of citizens". ${ }^{3}$

* LLD candidate (University of South Africa); LLM in human rights law (University of Cape Town); Licence en Droit (Université Protestante au Congo); legal consultant at The Carter Center, USA; continuing legal education expert (consultant) at The American Bar Association "Rule of Law Initiative", USA. This article is an adaptation of a paper presented at the annual Conference of the African Network of Constitutional Lawyers in 2009. The author would like to thank Casondra Turner for her assistance with this article.

1 P Shivute "Judicial independence and the responsibilities of a judicial officer" (paper presented at the Magistrates' Symposium, Windhoek, 12 June 2004) at 5.

2 CL Keith "Judicial independence and human rights protection around the world" (2002) Judiciature 195.

3 Consultative Council of European Judges "Recommendation on the independence, efficiency and role of judges and the relevance of its standards and any other international 
Accordingly, numerous international human rights instruments have included provisions dealing with an independent and impartial judiciary, such as the Universal Declaration of Human Rights, ${ }^{4}$ International Covenant on Civil and Political Rights ${ }^{5}$ and African Charter of Human and Peoples' Rights. ${ }^{6}$

In the Democratic Republic of Congo (DRC), the judiciary's independence has also been proclaimed through successive constitutions adopted by the country. However, although constitutional provisions have proclaimed judicial independence in the DRC, history reveals the vulnerability of the judiciary to manipulation by other institutions. Most legislation, enacted under the "dictatorial regime", invested the president of the Republic and minister of justice with significant power regarding the recruitment, promotion and remuneration of judicial officers. This legislation included in particular Ordinance No 87-394 of 1987 on the Organization and Functioning of the Supreme Council of the Judiciary (Ordinance on the Organization and Functioning of the CSM) and Ordinance No 88-056 of 1988 on the Status of Magistrates (Ordinance on the Status of Magistrates). For instance, article 1(4) of the Ordinance on the Status of Magistrates stipulates that no-one should be appointed as a magistrate if they are not a "good militant" of the ruling party Mouvement Populaire de la Révolution [Popular Movement of the Revolution] (MPR). The appointed judges and public prosecutors should pledge fidelity to the ruling party and president of the Republic before taking office. ${ }^{7}$ Also, the president set magistrates' initial salaries. ${ }^{8}$

With the advent of "the era of democracy" in 2006, the newly written constitution (2006 Constitution) conferred the running of the judiciary to a judicial organ called the Supreme Council of the Judiciary (CSM). ${ }^{9}$ Additionally, the 2006 Constitution compelled lawmakers to pass new legislation to regulate the organization and function of the judiciary. As a result, Law No 06/020 of 2006 on the Status of Magistrates (Law on the Status of Magistrates) and Law No 08/013 of 2008 on the Organization and Functioning of the Supreme Council of the Judiciary (Law on the Organization and Functioning of the CSM) were enacted. The second of these laws extended the scope of the CSM's competence to elaborate upon propositions regarding the recruitment or removal of magistrates, and produce and manage an independent budget for the

contd

standards to current problems in these fields" (2001) OP no 1 at 3, available at: <http:// www.coe.int/t/dghl/monitoring/greco/evaluations/round4/CCJE\%20Opinion\%201_EN. pdf> (last accessed 9 May 2012).

4 Art 10

5 Art 14(1).

6 Art 26 .

7 Ordinance on the Status of Magistrates, art 5.

$8 \mathrm{Id}$, art 16.

92006 Constitution, art 152(1). 
judiciary. ${ }^{10}$ The new laws also redefined the process for appointing magistrates as a merit-based process, ${ }^{11}$ reduced some supremacy of the executive over the judiciary, and reinforced the CSM's prerogatives. ${ }^{12}$

In light of these reforms, the question posed is whether judicial independence in the DRC is becoming a reality. If not, what are the challenges that risk inhibiting effective judicial independence?

This article argues that, even if the provisions of the Laws on the Status of Magistrates and on the Organization and Functioning of the CSM constitute an important step toward judicial independence by increasing the CSM's competence and reducing some traditional control of the executive over the judiciary, they still do not confer absolute independence on the judiciary.

\section{Background to DRC Republics}

This article examines the question of judicial independence in the DRC with regard to two periods: prior to the "Third Republic" and after the "Third Republic".

In the DRC, the chronology of "Republics" (regimes) may be presented as follows. The First Republic endured five years, from the country's independence in 1960 to 1965 . The Second Republic was the longest regime, lasting from 1965 to 2006. It was mostly characterized by the "dictatorial" regime of Mobutu Sese Seko between 1965 and 1997 and a long period of transition from 1997 to 2006. The Third Republic began with the adoption by referendum of the 2006 Constitution, also known as the Constitution of the Third Republic, which led to the organization of the first democratic elections in 2006.13

\section{JUDICIAL INDEPENDENCE PRIOR TO THE "THIRD REPUBLIC"}

\section{Overview of constitutional and statutory compliance with the requirements of judicial independence}

All constitutional dispositions promulgated in the DRC prior to "the Third Republic", from the 1960 Fundamental Law on the Structure of the Belgian Congo $^{14}$ to the Constitution of Transition of 2003 (2003 Constitution), ${ }^{15}$ have affirmed the principle of judicial independence.

10 Law on the Organization and Functioning of the CSM, art 2.

11 Law on the Status of Magistrates, art 1.

12 Id, preamble.

13 B Kabamba et al "Premiers scrutins de la Troisième République Démocratique du Congo. Analyse des résultats" ["First elections of the Third Democratic Republic of Congo: Analysis of results"] (2007) 7 Federalisme Regionalisme [Federalism Regionalism], available at: <http://popups.ulg.ac.be/federalisme/document.php?id=552> (last accessed 9 May 2012).

14 Art $187(1)$.

15 Art 147(1). 
Article 147(1) of the 2003 Constitution stated: "the judiciary power is independent from the legislative power and executive power". The 2003 Constitution also emphasized that justice is administered in the name of the Congolese people, ${ }^{16}$ and that judges are only under the authority of law while exercising judicial functions. ${ }^{17}$

Yet, the modalities relating to the organization of the judiciary were regulated by the Ordinances on the Organization and Functioning of the CSM and on the Status of Magistrates. Both ordinances also reaffirmed the principle of the independence of magistrates vis-à-vis persons to whom their decisions must be applied.

\section{The concept of "magistrate" under Congolese law}

The scope of the meaning of the word "magistrate" differs from one legal system to another. From the common law jurisdiction's perspective, for instance, a magistrate is a judicial officer whose function is to hear prosecutions for summary offences. ${ }^{18}$ In England and Wales and the United States of America, magistrates have limited powers and perform at the court of the lowest level (magistrates court), which adjudicates minor crimes and possesses narrow sentencing powers, limited to shorter periods of custody, fines, probation and community service orders, as well as a miscellany of other options. ${ }^{19}$

On the other hand, in countries under the influence of the civil law system, such as France, Italy, Belgium, Benin and the DRC, a "magistrate" is a judicial officer with broad investigatory powers, who acts as a judge or public prosecutor. In the Congolese context, the Ordinances on the Organization and Functioning of the CSM and on the Status of Magistrates use the generic term "magistrate" to refer to judicial officers. There is, however, a difference between magistrat du siège [judge] and magistrat débout or officier du ministère public [public prosecutor]. Unlike the magistrat du siège, the magistrat débout or officier du ministère public has a hybrid nature, to the extent that he or she is considered a "judicial officer" and "functionary" of the state. In any case, both the magistrat $d u$ siège and the magistrat débout are governed by the same statutes and recruited in the same way.

\section{Control of the president of the Republic and the minister of justice over the judiciary}

Under the Constitution of the Republic of Zaire $1983,{ }^{20}$ the judiciary was considered a mere organ of the ruling party (the MPR) rather than an autonomous

\footnotetext{
16 Id, art 146(1).

17 Id, art 147(4).

18 T Gallagher "Criminal law: A critical analysis of the magistrate court", available at: <http://www.huntlycomputers.co.uk/criminal-justice-system.html> (last accessed 3 May 2012).

19 Ibid.

20 Promulgated on 1 January 1983 and revised on 27 June 1988.
} 
political institution. As such, the president of the MPR, who was president of the Republic, had the right to monitor the functioning of all organs of his political party, including the judiciary. ${ }^{21}$

Article 147(2) of the 2003 Constitution also provided that the president of the Republic was the guarantor of the judiciary's independence, assisted by the CSM.

In the same way, article 10 of the Code of Judicial Organization and Competence of 1982 (COCJ) provides that the officiers $d u$ ministère public are placed under the authority of the minister of justice. As already mentioned, the Congolese public prosecutor has a hybrid nature to the extent that he or she is considered to be a "judicial officer" and a "functionary" of the state. This state of affairs limits the independence of the public prosecutor because he or she is under the direction and supervision of both his or her superiors and the minister of justice. Not surprisingly, the minister of justice usually compels the procureur général de la République [general prosecutor of the Republic] to initiate or dismiss any investigation. ${ }^{22}$

\section{Qualification and process of the appointment of magistrates}

Article 1 of the Ordinance on the Status of Magistrates stated:

"No one shall be appointed a magistrate if he / she does not satisfy the requirements listed below:

1. To possess Congolese nationality,

2. To be aged 21 years and not have exceeded 35 years,

3. To enjoy full rights of citizenship,

4. To be a good militant of the Popular Movement of the Revolution (MPR) and enjoy a perfect morality evidenced by a certificate issued by the administrative authority or by a criminal record,

5. To be physically apt,

6. To hold a law degree,

7. To produce written permission from her spouse, in the case of a married woman,

8. To have successfully passed the recruitment examination."

It appears from this provision that the recruitment of judicial officials was not based only on merit, having regard to qualifications, integrity, ability and efficiency. In addition, article 1(4) required candidates to be good militants of the ruling party, so that a candidate who did not share the philosophical ideology

21 Id, art 36: "The president of the MPR is by right the president of the Republic ... he monitors the proper functioning of all organs of the MPR."

22 COCJ, art 12(2): "The general prosecutor of the Republic shall, on the order of the minister of justice, initiate or continue the investigation of any offences." 
of the ruling party could not be appointed as a judge or public prosecutor, no matter whether he or she met the other requirements.

Yet the president of the Republic, acting on the proposition of the chairman of the CSM, appointed candidates who successfully met the requirements enumerated in article 1 of the ordinance. ${ }^{23}$ However, the president of the Republic could also, upon his own initiative, appoint judges or public prosecutors to any grade, including to the Supreme Court of Justice. ${ }^{24}$

Article 5 of the Ordinance on the Status of Magistrates provided that the appointed and / or promoted judges and public prosecutors should, before taking office, pledge fidelity to the ruling party and president of the Republic, and promise to respect the laws of the country. ${ }^{25}$ Such an imposition to pledge fidelity to the president of the Republic and his party negatively impacted the independence of judicial officers.

\section{Supreme Council of the Judiciary}

By virtue of article 1 of the Ordinance on the Organization and Functioning of the CSM, the CSM was to exercise disciplinary authority over all magistrats (both judges and public prosecutors) and there were elaborate provisions regarding the appointment and promotion of magistrates.

The law did not determine clearly the real composition of the CSM. In exercising its function of disciplinary authority, the CSM was composed of at least three members, depending on the rank of the relevant magistrate. ${ }^{26}$ In performing its function as a consultative organ regarding the proposition of magistrates to be promoted, the CSM was composed of numerous members, including the chairman of the Judicial Council, presidents of the Supreme Court of Justice, first attorney general of the Republic, first presidents of the Courts of Appeal, first president of the Court of State Security, and attorneys general at the Courts of Appeal and Court of State Security. ${ }^{27}$ However, the ordinance was "silent" about the composition of the CSM in the context of elaborating propositions regarding the appointment of magistrates.

23 Ordinance on the Organization and Functioning of the CSM, art 3(2).

24 Id, art 4: "Exceptionally, the president of the Republic can appoint as judges or public prosecutors to any grade, either on his own initiative or at the request of the president of the CSM or the Bureau of the CSM, any persons who satisfy the conditions of article 1." The text of the pledge read: "I swear loyalty to the president of the MPR, the president of the Republic, and obedience to the constitution and to the laws of the Republic of Zaire." Ordinance on the Organization and Functioning of the CSM, art 2(2). When the pursued magistrate ranked lower than the president of the Court of Appeal or the Court of State Security or general advocate, the CSM was composed of the chairman of the Judicial Council, the first president of the Court of Appeal or Court of State Security, and the general attorney at the Court of Appeal or Court of State Security. When the pursued magistrate ranked higher than the president of the Court of Appeal or the Court of State Security or attorney general, the CSM was composed of the chairman of the Judicial Council, the first president of the Supreme Court of Justice and the attorney general of the Republic. 
The composition of the CSM has always been a much debated issue in the DRC. The draft constitution of 1967 recommended that the president of the Republic and minister of justice be, respectively, president and vice-president of the CSM. ${ }^{28}$ Even recently, some members of Parliament affiliated with the ruling party recommended that the president of the Republic be the chairman of the CSM.

\section{Disciplinary proceedings}

Article 40 of the Ordinance on the Status of Magistrates stated that any misbehaviour by a magistrate in performing his or her duty constituted a disciplinary fault. The chairman of the CSM, chiefs of jurisdictions and chiefs of the offices of the prosecutor who observed misconduct committed by a magistrate under their authorities ${ }^{29}$ were to appoint another magistrate to inquire into the matter. ${ }^{30}$ The magistrate appointed to conduct the inquiry should have at least the same rank as the magistrate accused. ${ }^{31}$ He or she had to report back to the chairman of the Judicial Council, chiefs of jurisdictions or chiefs of the offices of the prosecutor, ${ }^{32}$ who would decide whether or not the magistrate accused should be sued before the CSM.

The accused magistrate could appear in person before the CSM or be assisted by a legal representative. ${ }^{33}$ If convicted, the magistrate could face one of the following sanctions: warning, retention of salary, suspension or removal. ${ }^{34}$ Yet, the CSM could only pronounce one of the first three sentences (ie warning, retention of salary or suspension). The CSM could only propose to the president of the Republic that a convicted magistrate be removed. ${ }^{35}$ The CSM's decision was reputed to be rendered in the first and last resort, ${ }^{36}$ so a convicted magistrate could not appeal against the decision.

On 6 November 1998, President Laurent-Désiré Kabila unilaterally removed 315 magistrates on the grounds of "immorality, corruption, desertion, incompetence, and conduct incompatible with the duties of magistrates". ${ }^{37}$ That decision was administratively abusive and illegal, to the extent that the CSM was not involved and the magistrates removed had no opportunity to defend themselves.

28 Art 64(2): "It shall be for a separate law to prescribe the composition, organisation and functioning of the CSM. Notwithstanding, the president of the Republic and minister of justice shall be the president and vice-president of the Council respectively." See also: Moniteur Congolais No 14 [The Congolese Monitor] (15 July 1967) at 561. Ordinance on the Status of Magistrates, art 43.

30 Id, art 45(1).

31 Id, art 45(2).

32 Id, art 45(5).

33 Id, art 49(3).

34 Id, art 41.

35 Id, art 42.

36 Id, art 11(2).

37 Decree No 144 of 6 November 1998 on the Dismissal of Magistrates. 


\section{Remuneration and financial autonomy of magistrates}

Under the Ordinance on the Status of Magistrates, magistrates had rights to salary $^{38}$ and other social advantages, including familial allowance, housing allowance, healthcare services, vacation pay, transportation grants, allowance of invalidity, funeral expenses and other advantages granted to public servants. ${ }^{39}$ Article 16 of the ordinance also stipulated that the initial salaries of magistrats (both judges and public prosecutors, at all grades) be fixed by the president of the Republic on proposition of the chairman of the CSM.

It is noteworthy that there was no autonomous budget for the functioning of the judiciary or the salaries of its operators. This state of affairs had serious negative implications for the financial independence of the judiciary.

\section{JUDICIAL INDEPENDENCE UNDER THE "THIRD REPUBLIC"}

Similar to its predecessors, the 2006 Constitution also reaffirms the principle of judicial independence, ${ }^{40}$ which is the corollary of the doctrine of separation of powers. However, unlike its predecessors, the 2006 Constitution introduces significant reforms regarding the organization and running of the judiciary. In order to give effect to the constitutional provisions, novel legislation regulating the modalities of the functioning of the judiciary has been enacted, including the Laws on the Status of Magistrates and on the Organization and Functioning of the CSM. So, what is the scope of these reforms?

\section{Augmentation of the power of the CSM}

Article 152(1) of the 2006 Constitution stipulates that the CSM is the ruling authority of the judiciary. The CSM's role is no longer limited to that of a disciplinary authority and consultative organ. Instead, the new Law on the Organization and Functioning of the CSM has broadened the CSM's competence to include: providing advice on clemency; determining the rotation of judges; supervising non-magistrate / judicial personnel; and elaborating an independent budget for the judiciary. ${ }^{41}$

\section{Composition of the CSM}

The composition of the CSM is explicitly mentioned for the first time in the 2006 Constitution. Article 152(2) clearly states that the CSM should be solely composed of magistrats (both judges and public prosecutors). ${ }^{42}$

\footnotetext{
38 Ordinance on the Status of Magistrates, art 16.

39 Id, art 21.

402006 Constitution, art 149(1).

41 Law on the Organization and Functioning of the CSM, art 2.

422006 Constitution, art 156(2): "The CSM is composed of the president of the Constitutional Court, general prosecutor at the Constitutional Court, first president of the Court of Cassation, general prosecutor at the Court of Cassation, first president of the Council of State, general prosecutor at the Council of State, first president of the High Military Court, auditor general at the High Military Court, first presidents of
} 
In defining the CSM's composition, the drafters of the constitution were anxious to end executive control of the judiciary. Preventing non-magistrates from sitting in the CSM seems to constitute an important step toward judicial independence in the DRC. It should however be noted that, despite a clear constitutional stipulation, the debate on the composition of the CSM is far from over, because a group of parliamentarians has suggested an amendment to the constitution on the composition of the CSM in order to allow the president of Republic to sit as a member of the CSM. ${ }^{43}$

The supporters of that petition referred to other francophone (African) countries in which both magistrates and non-magistrates still sit on the relevant judicial council. These countries include Burkina-Faso, ${ }^{44}$ Senegal ${ }^{45}$ and Benin. ${ }^{46}$ For example, the Beninese "organic law" on its Supreme Council of the Judiciary provides that the council is composed of membres de droit [members of the law] and autres membres [other members]. Membres de droit include, for instance, the president of the Republic (as a chairperson), the president of the Supreme Court (as the first vice-president), the minister of justice (as the second vice-president), the president of the Court of Appeal and the general prosecutor. Autres membres comprise a non-magistrate personality known for their intellectual and moral abilities (not necessarily a legal practitioner) ${ }^{47}$ and two magistrates. ${ }^{48}$

However, even in Benin and / or Senegal, the consortia of magistrates are now calling unanimously for the reform of their respective councils to limit their composition to magistrates. ${ }^{49}$ They are thereby following the position taken under Congolese law, which seems to be advanced on that point.

contd

Courts of Appeal, prosecutors at the Courts of Appeal, first presidents of the Administrative Courts of Appeal, prosecutors at the Administrative Courts of Appeal, first presidents of the Military Courts, auditors military superiors, two judges from each Court of Appeal, two public prosecutors attached to each Court of Appeal, one judge from each Military Court, and one public prosecutor attached to each Military Court."

43 "La révision de la constitution est le prélude de la 'monarchisation' des institutions" ["The revision of the constitution is a prelude to the 'monarchization' of institutions"] (28 November 2007) Le Potentiel [The Potential], available at: <http://www.lepotentiel.com /afficher_article.php?id_edition=\&id_article=56061> (last accessed 9 May 2012).

44 Art 132 of the constitution (Law No 002/97/ADP of 27 January 1997).

45 "Les Conseils Supérieurs de la Magistrature ou organes equivalents en Afrique: Brève présentation comparative de leur pouvoirs et compositions" ["Supreme Councils of Judiciary or equivalent organs in Africa: A short presentation comparing their powers and compositions"] (November 2007), available at: <http://www.afrimap.org/english /images/research_pdf/CSM_en_Afrique.pdf> (last accessed 9 May 2012).

46 J Djogbenou "Bénin: Secteur de la justice et l'état de droit" ["Benin: The justice sector and the state of the law"] (2010), available at: <http://www.afrimap.org/english/images/rep ort/AfriMAP_Benin_Justice_Principal.pdf> (last accessed 12 December 2010). "Les Conseils Supérieurs", above at note 45.

48 Ibid.

49 Djogbenou "Bénin", above at note 46. 


\section{Structures of the CSM}

Article 5 of the Law on the Organization and Functioning of the CSM states: "[t]he structures of the Supreme Council of Judiciary are the: General Assembly, Bureau, Disciplinary Chambers, and Permanent Secretariat". The General Assembly, which comprises all members, is the organ which orients and takes decisions on matters within the jurisdiction of the CSM. ${ }^{50}$ The Bureau executes the decisions taken and recommendations made by the General Assembly. ${ }^{51}$ It is composed of eight members, including the president of the Constitutional Court, general prosecutor at the Constitutional Court, first president of the Court of Cassation, general prosecutor at the Court of Cassation, first president of the Council of State, general prosecutor at the Council of State, first president of the High Military Court and auditor general at the High Military Court. Article 18 of the same law provides that the president of the Constitutional Court is the chairman of the CSM and leads the Bureau.

It should be noted that, inspired by the French model, the 2006 Constitution and the Law on the Organization and Functioning of the CSM have introduced a novel structure to the Congolese justice system. This structure relates to the establishment of dual jurisdictions: the Court of Cassation and the Council of State, which are, respectively, judicial and administrative jurisdictions. However, alongside the Court of Cassation and the Council of State, the constitution also created a Constitutional Court whose scope of competence includes monitoring the constitutionality of laws and acts with the force of law, and adjudicating electoral disputes. ${ }^{52}$ Under the constitution, the Constitutional Court, Court of Cassation and Council of State should be installed to replace the Supreme Court of Justice. However, no such installation or replacement is yet effective. Predicting a delay in setting up the new institutions, article 44(1) of the Law on the Organization and Functioning of the CSM provides that, before the installation of the Constitutional Court, Council of State, Court of Cassation, Administrative Court of Appeal and offices of the public prosecutor attached to these courts, the CSM should operate on the basis of those courts which are actually installed. Therefore, the CSM should be headed by the first president of the Supreme Court of Justice.

\section{Qualification and process of the appointment of magistrates}

Article 1 of the Law on the Status of Magistrates states:

"No one shall be appointed a magistrate if he or she does not satisfy the requirements listed below:

1. To possess Congolese nationality,

50 Law on the Organization and Functioning of the CSM, art 6.

51 Id, art 17(1).

522006 Constitution, arts 160-62. 
2. To be aged 21 years and not have exceeded 40 years,

3. To enjoy full rights of citizenship,

4. To enjoy a perfect morality evidenced by a certificate issued by the administrative authority or by a criminal record,

5. To possess physical and mental aptitude evidenced by a medical certificate,

6. To hold a law degree,

7. To produce a certificate of marriage, in the case of a married candidate."

It can be observed from this provision that the Law on the Status of Magistrates removed the condition requiring a candidate to be a "good militant" of the ruling party. Instead, it has solely based recruitment on merit, having regard to qualifications, integrity, ability and efficiency. Article 2 of the new law emphasizes that recruitment of a magistrate follows an examination. The process of recruitment should be initiated by the CSM and the call for candidates should be published. This is a significant step toward judicial independence.

Although the president of the Republic still conserves his constitutional prerogative to appoint magistrates, the CSM's advice over the appointment of magistrate candidates is mandatory. ${ }^{53}$ This is intended to limit the risk that the president could appoint magistrates on his own initiative.

Concerning the appointment of the judges of the Constitutional Court, article 158(1) of the 2006 Constitution provides that: "[t]he Constitutional Court consists of nine members appointed by the president of the Republic, three of whom are appointed on his own initiative, three chosen by Parliament, and three chosen by the Supreme Council of the Judiciary."

Unlike for other magistrates, it appears from this provision that the selection of Constitutional Court judges is based on a political approach. Such an approach is common in some countries, such as France, Benin, Belgium and Mali, where the Constitutional Court judges are selected by politicians (government and Parliament) rather than by judicial institutions. ${ }^{54}$ Considering the important role played by the Constitutional Court, the strong involvement of politicians in the process of selecting its judges is very dangerous, because some Constitutional Court judges may attempt to deliver judgments, for instance in the case of electoral disputes, in favour of the politicians who selected them, thereby losing their independence.

In the Congolese context, one may theoretically argue that the participation of the CSM alongside politicians in the process of appointing Constitutional Court judges constitutes a mechanism to attenuate the risk of the "politicization" of the process. However, in practice, the danger of the "politicization" of

53 Law on the Status of Magistrates, art 2.

54 "Étude de législation comparée: La composition des cours constitutionnelles" ["Comparative study of legislation: The composition of constitutional courts"] (November 2007) Service des Études Juridiques [Legal Studies Service], available at: <http:// www.senat.fr/lc/lc179/lc179_mono.html> (last accessed 9 May 2012). 
the Constitutional Court is still present, given that two out of three judges of the highest court of the country should be selected by politicians sitting in government and Parliament.

If the constitutional prerogative of the president in appointing magistrates must remain unquestioned, then it is suggested that all nine judges of the Constitutional Court be chosen by the CSM or judicial institutions. This is the case in Luxemburg, where four of the nine members comprising the Constitutional Court are the most senior judges in the country (and are considered to be members of law), and the other five are appointed at the proposition of the Supreme Court. ${ }^{55}$

\section{Oath before taking office}

Under article 5 of the Law on the Status of Magistrates, appointed or promoted magistrates should, prior to taking office, pledge obedience to the constitution and laws of the country rather than to the ruling party and the president of the Republic, as had been stipulated before. The oath should be taken before the court or office of the public prosecutor to which the judicial officer is appointed. ${ }^{56}$

However, article 13(3) of the same law states that magistrates appointed to the Court of Cassation or Council of State should take their oath before the president of the Republic. So, one wonders whether such a pledge of the highest magistrates before the president of the Republic is not rather a symbol of their fidelity to the head of the executive.

\section{Autonomy of public prosecutor and irremovability of judges}

Autonomy of the public prosecutor

Article 15(1) of the Law on the Status of Magistrates provides that the magistrat $d u$ parquet [public prosecutor] performs his or her duty under the authority of his or her hierarchical superiors, whereas previously he or she had been under the authority of the minister of justice. ${ }^{57}$ Article 15(2) adds emphasis by stipulating that, without prejudice to the constitutional provisions, the minister of justice "may", without interfering in the course of the investigation, demand that the general prosecutor at the Court of Cassation investigate the crimes committed within the court's jurisdiction. Such wording is meant to clarify that the general prosecutor should independently open any criminal investigation at his or her own discretion. In the meantime, the COCJ, which remains in effect, states that the general prosecutor of the Republic is under the supervision of the minister of justice, with the effect that the latter can compel the general prosecutor to initiate or dismiss any investigation. ${ }^{58}$

\footnotetext{
55 Ibid.

56 Law on the Status of Magistrates, art 13(1).

57 COCJ, art 10: "Officers of the public prosecutor are under the authority of the minister of justice."

58 Id, art 12.
} 
Compared to the COCJ, the Law on the Status of Magistrates seems to free the public prosecutor from the authority of the minister of justice.

However, the recently promulgated Law No 11/002 of 2011 amending some provisions of the 2006 Constitution (2011 Amendment Law) has revised article 149 of the constitution, which proclaims the independence of the judiciary. The amendment deletes the last sentence of article 149(1) which named the Parquet [office of the public prosecutor] as a part of judicial power, implying that the public prosecutor is no longer a "judicial officer". Instead, he becomes solely a "functionary of the state", thereby placed under the authority of the minister of justice. This constitutional revision may also raise concerns about the legality of the general prosecutor sitting in the CSM. Under article 152 of the constitution, the CSM is the ruling authority of the judiciary and should only be composed of judicial officers. Since the general prosecutor of the Republic is now considered a "functionary of the state" rather than a "judicial officer", then he or she should cease sitting in the CSM.

Yet, the preamble of the 2011 Amendment Law stipulates that the revision of article 149 tends to harmonize the provisions of article 149 with those of articles 150 and 151 of the constitution, which proclaim only the independence of the magistrat du siège [judge] in his mission to say the law.

In the view of the author, the revision of article 149 was unnecessary. The intention behind that amendment seems to be to reinforce the government's control over the judiciary.

\section{Irremovability of judges}

Articles 150 of the 2006 Constitution and 14 of the Law on the Status of Magistrates provide that judges are irremovable, meaning that they cannot be promoted or transferred to another position or court without their consent. ${ }^{59}$ The Beninese Law on the Status of Magistrates states that the irremovability of magistrates does not constitute a personal privilege for a judge. ${ }^{60}$ Instead, it is a fundamental tenet of judicial independence because it represents a safeguard against an "unfair" appointment or assignment to a different office or location as a reprisal to any judgment that the judge might deliver.

Although both the judge and public prosecutor are referenced under the generic term magistrat, it should be noted that the benefit of irremovability only covers the magistrat de siege rather than magistrats $d u$ parquet. This is because the magistrats $d u$ parquet were technically considered to be both judicial officers and functionaries of the state. Furthermore, the 2011 Amendment Law also reaffirmed the exclusion of magistrats du parquet from the privilege of irremovability since they are now considered solely as functionaries of the state.

59 The 2006 Constitution, art 150 and the Law on the Status of Magistrates, art 14.

60 Art 23. See also: "Les Conseils Supérieurs", above at note 45 at 2. 
Irremovability grants tenure to the judge until a mandatory retirement age or the expiry of a fixed term of office. ${ }^{61}$ Most countries, with the notable exception of the Czech Republic, ${ }^{62}$ set a compulsory retirement age, for example: France (67 years), ${ }^{63}$ Malawi (65 years) ${ }^{64}$ and the United States of America (between 70 and 75 years, with a lifetime appointment for Supreme Court judges). ${ }^{65}$ Congolese law sets 70 years as the compulsory retirement age for magistrates from the Court of Cassation and Council of State, and 65 years for those from the lower courts. ${ }^{66}$ However, magistrates who reach 35 years of continuous service may be eligible for retirement and those who reach 55 years of age and have served for 25 years may request early retirement. ${ }^{67}$

\section{Disciplinary proceedings}

Any misbehaviour by a magistrate in performing his or her duties constitutes a disciplinary fault. Article 47 of the Law on the Status of Magistrates provides:

"The disciplinary fault consists of:

1) The fact that a public prosecutor does not to give his or her advice within ten days in a criminal action, 30 days in a labour, civil or commercial action;

2) The fact that judges do not to make a decision within the same timeframe;

3) The fact that a magistrate seeks directly or indirectly to contact the parties before giving his or her advice or making a decision;

4) The fact of performing arbitrary arrests and detentions;

5) The fact of failing to inform the accused person of their rights under articles 17 and 18 of the constitution;

6) The fact of encouraging or performing torture;

7) The fact that a magistrate violates the terms of his or her oath;

8) The fact that a magistrate is guilty of torture or other cruel, inhuman, degrading or harassing treatment or sexual violence during the investigation."

Unlike its predecessor, the Law on the Status of Magistrates clearly defines what constitutes a disciplinary fault. In most countries, from both civil law

61 Consultative Council of European Judges "Recommendation", above at note 3 at 13.

62 Ibid.

63 "Organic Law" No 2010-1341 of 10 November 2010 on the Age Limit for Magistrates of the Judiciary.

64 Van de Vijver The Judicial Institution in Southern Africa, above at note 47 at 80.

65 SD Makar "In praise of older judges: Raise the mandatory retirement age?" (1997) LXXI/4 Florida Bar Journal 48, available at: <http://www.floridabar.org/divcom/jn/jnjournal01. nsf> (last accessed 12 December 2010).

66 Law on the Status of Magistrates, art 70.

67 Ibid. 
and common law jurisdictions, disciplinary power is exercised by the CSM or equivalent organ; however in some countries, disciplinary power is exercised by two different organs depending on whether the misconduct is committed by a judge or public prosecutor. For instance, in France ${ }^{68}$ and Mozambique, ${ }^{69}$ disciplinary action over a judge is governed by the relevant CSM, while it is governed by the minister of justice when the professional misconduct is committed by the public prosecutor. In Lesotho, there is no disciplinary power in relation to judicial personnel. However, the prime minister can set up and select the members of a (special) disciplinary tribunal to adjudicate misbehaviour committed by judicial officers. ${ }^{70}$ In the Congolese context, disciplinary jurisdiction over magistrates (both judges and public prosecutors) is the preserve of a "bicameral" $\mathrm{CSM}^{71}$ consisting of two chambers of discipline: the "national chamber" and "provincial chamber". ${ }^{72}$

The provincial chamber has jurisdiction over disciplinary faults committed by magistrates from low-level tribunals and from the Courts of Appeal, Administrative Courts of Appeal, Military Courts and offices of public prosecutors attached to those courts. ${ }^{73}$ The national chamber of discipline has jurisdiction, as a first and last resort, over disciplinary faults committed by magistrates of the Court of Cassation, Council of State, High Military Court and offices of the public prosecutors attached to those courts. ${ }^{74}$ The national chamber of discipline also serves as a jurisdiction of appeal over decisions rendered by the provincial chamber. ${ }^{75}$ Article 23(3) of the Law on the Organization and Functioning of the CSM states, however, that the disciplinary regime of magistrates from the Constitutional Court should be governed by an "organic law" on the organization and function of that court. Such legislation has not yet been passed. However, the disciplinary chambers of the CSM can currently receive complaints against a magistrate from: chiefs of jurisdictions or chiefs of the offices of the prosecutor under whom the accused magistrate is working; ${ }^{76}$ the minister of justice; ${ }^{77}$ or any interested individuals. ${ }^{78}$ This provision is innovative to the extent that it entitles individuals to approach the CSM in order to file complaints against magistrates alleging professional misconduct whereas, under the previous legislation, individuals were prevented from doing so. $58-1270$ of 22 December 1958 on the Status of the Magistrature.

69 "Les Conseils Supérieurs", above at note 45 at 5.

70 Constitution of Lesotho, sec 125.

71 Law on the Organization and Functioning of the CSM, art 20.

72 Id, arts 22 and 23(1).

73 Id, art 22.

74 Id, art 23(1).

75 Id, art 23(2).

76 Law on the Status of Magistrates, art 50.

77 Law on the Organization and Functioning of the CSM, art 28(2).

78 Ibid. 
However, such a procedure of authorizing the public to complain against the wrongdoing of magistrates is not really new under Congolese law, because the Code of Civil Procedure, through the procedure called prise à partie, recognizes a litigant party's right to file a complaint before the Supreme Court of Justice against a magistrate who has committed fraud, embezzlement, gross negligence or miscarriage of justice. ${ }^{79}$

Unlike the Congolese Code of Civil Procedure, which requires the prior approval of the president of the Supreme Court of Justice before prise à partie is implemented, ${ }^{80}$ there is no such a requirement under the Law on the Organization and Functioning of the CSM, so individuals may approach the disciplinary chambers of the CSM direct, without going through the chiefs of jurisdictions (or the offices of the prosecutor). According to the preamble to that law, the permission given to the disciplinary chambers to accept complaints from individuals is motivated by the assumption that judicial independence is not only a right of magistrates but is also a fundamental right for litigants. ${ }^{81}$ The danger, though, is that it may "open the door" to the potential risk of direct or indirect interference from non-judicial actors over the business of the judiciary.

The disciplinary procedure is a "quasi-judicial" process; the magistrate accused should enjoy the right to a fair trial, including the presumption of innocence, the right to be informed about the charges against him or her ${ }^{82}$ and the right to be assisted by a legal representative. As stated above, the disciplinary chambers can only issue one of the following sanctions: a warning, retention of salary or suspension. The removal of a magistrate can only be decided by the president of the Republic, acting on the CSM's recommendation. ${ }^{83}$ With the delay regarding the establishment of the CSM, however, observers noted that the president signed a number of decrees in March 2008 through which he, on his own initiative, removed some magistrates from office. ${ }^{84}$

Furthermore, in April 2010, the minister of justice submitted to Parliament a draft law which intends to amend some provisions of the Law on the Status of Magistrates. ${ }^{85}$ Under that draft law, once the prise à partie action is filed, the

79 Code of Civil Procedure (1960), arts 96-104.

80 Ordinance No 82-017 on the Procedure Before the Supreme Court of Justice, art 60.

81 Preamble to the Law on the Organization and Functioning of the CSM.

82 Law on the Status of Magistrates, arts 57 and 58.

83 Id, art 49.

84 S Bolle "RD Congo: J Kabila pouvait-il purger la magistrature en l'absence du CSM de la Constitution de 2006?" [DR of Congo: Can J Kabila purge the magistrature in the absence of the CSM from the constitution of 2006?"] (9 March 2008) La Constitution en Afrique [The Constitution in Africa], available at: <http://www.la-constitution-en-afrique. org/article-17496115.html> (last accessed 9 May 2012).

85 "Grève des magistrats: Mot d'ordre diversement suivi” ["Magistrates' strike: Order followed to varying degrees"] (29 March 2010) Radio Okapi, available at: <http://radio okapi.net/actualite/2010/03/29/greve-des-magistrats-le-mot-dordre-est-diversementsuivi/> (last accessed 9 May 2012). 
accused magistrate will immediately be suspended and deprived of his or her salary. To the inter-syndicate of magistrates, the draft law is merely a manoeuvre by the government to impede the independence of the judiciary. ${ }^{86}$

It should however be noted that disciplinary action remains separate and independent from criminal action, which may be filed on the basis of the same facts. ${ }^{87}$ Under the Law on the Status of Magistrates, a magistrate who is condemned to a term of imprisonment exceeding three months should be removed from office. ${ }^{88}$ Yet, the draft law proposed by the minister of justice suggests that a magistrate who receives a custodial sentence for any criminal act should immediately be removed from office regardless of the term of his or her imprisonment (even for a jail term of one day).

\section{Remuneration and financial autonomy of magistrates}

Article 25 of the Law on the Status of Magistrates states that magistrates should receive adequate remuneration and social advantages to enable them to consolidate their independence. In the same way, the 2006 Constitution and the Law on the Organization and Functioning of the CSM provide that the judiciary should have its own budget that will be defined and administered by the CSM. ${ }^{89}$ This is the first time the judiciary has enjoyed financial autonomy in the DRC. Previously, the remuneration of judicial officers was determined by the president of the Republic; ${ }^{90}$ this gave him significant power to control the magistrates financially.

Compared to some other African countries such as Togo, ${ }^{91}$ Lesotho $^{92}$ or South Africa, ${ }^{93}$ where the salaries of magistrates are still determined by the executive, the current Congolese provisions constitute, in theory, an important step toward the financial autonomy of the judiciary. In practice, however, there are some omissions. On the one hand, although article 25 of the Law on the Status of Magistrates provides that magistrates should be remunerated to support their independence, it does not establish a remuneration scale to reflect the dignity of the profession and the burden of magistrates' responsibilities. On the other hand, the implementation of these statutory measures regarding the financial autonomy of the judiciary is not effective, since the

86 "Les magistrats Congolais s'opposent à la modification de leur statut" ["Congolese magistrates oppose changes to their status”] (23 March 2010) Radio Okapi, available at: <http:// radiookapi.net/emissions-audio/dialogue-entre-congolais/2010/03/23/ce-soir-les-magis trats-congolais-sopposent-a-la-modification-de-leur-statut/> (last accessed 9 May 2012).

87 Law on the Status of Magistrates, art 61(1).

88 Id, art 61(2).

89 Art 149(6) of the constitution and art 37(1) of the Law on the Organization and Functioning of the CSM.

90 Ordinance on the Status of Magistrates, art 16(1): "The initial salaries of each grade of magistrate are fixed by the president of the MPR, the president of the Republic."

91 "Organic Law" No 96-11 on Fixing the Status of Magistrates, art 42.

92 Van de Vijver The Judicial Institution in Southern Africa, above at note 47 at 64.

93 Judges' Remuneration and Conditions of Employment Act of 2001, sec 2. 
CSM itself is not yet fully established and does not have the financial resources for its own functioning. Consequently, magistrates are still remunerated by the executive, as are other public servants.

\section{RECOMMENDATIONS}

The following recommendations are therefore suggested.

First, the Bill on the Functioning of the Constitutional Court should be promulgated. Since its adoption by Parliament last year, this bill still awaits promulgation by the president of the Republic in order to become legally enforceable. ${ }^{94}$ The constitution specifies the installation of the Constitutional Court, Court of Cassation and Council of State to replace the current Supreme Court of Justice. As mentioned earlier, under the constitution, the CSM should be composed of magistrates from the Constitutional Court, Court of Cassation and Council of State and the offices of the public prosecutors attached to those fora. The absence of a law on the functioning of the Constitutional Court seems to be delaying the installation and functioning of the three new judicial institutions on the basis of which the running of the CSM will become more effective. However, it should also be noted that the delay regarding the establishment of these new judicial institutions is not absolutely critical for the efficient functioning of the CSM. This is because the Law on the Organization and Functioning of the CSM provides that, before the Constitutional Court, Council of State, Court of Cassation, Administrative Court of Appeal and offices of the public prosecutor attached to those courts are installed, the CSM should operate on the basis of those courts which are actually installed, and be headed by the first president of the Supreme Court of Justice.

Secondly, the procedure for selecting Constitutional Court judges should be reformed. All Constitutional Court judges should be selected by the CSM (which is the unique organ regulating the functioning of the judiciary) rather than by other branches of state such as the president of the Republic or Parliament. This change would enforce judges' independence, thereby avoiding the risk of "politicizing" the highest court of the country. Lessons should be learnt from the most recent electoral crisis in the DRC where, two weeks before the presidential elections, the incumbent president, Joseph Kabila, appointed 18 new judges (out of 26) to the Supreme Court of Justice (which is responsible for adjudicating election disputes). ${ }^{95}$ These judges refrained from invalidating the provisional election results, which would have been

94 "RDC: Adoption de la loi relative à la Cour Constitutionnelle" ["DRC: Adoption of the law on the Constitutional Court"] (12 April 2011) Culture Congolaise [Congolese Culture], available at: <http://www.culturecongolaise.net/?p=6324> (last accessed 9 May 2012).

95 UN Security Council "Report of the secretary-general on the United Nations organization stabilization mission in the Democratic Republic of the Congo" (January 2012) at 2, available at: <http://www.un.org/ga/search/view_doc.asp?symbol=S/2012/65> (last accessed 9 May 2012). 
to the detriment of the incumbent president. ${ }^{96}$ After the Independent National Election Commission (CENI) published the provisional election results, international and national election observers, political parties and the CENI itself admitted that there were irregularities during the process of tabulating the election results which had shown the incumbent president as the winner. ${ }^{97}$ Notwithstanding the recognition of those irregularities, the Supreme Court of Justice (which is legally entitled to declare the definitive results) validated the irregular results without any change, regardless of a petition calling for the nullification of those results which was introduced by an election contender. ${ }^{98}$

A very similar situation occurred in Côte d'Ivoire where the head of the Constitutional Council (equivalent to the Constitutional Court), who was appointed on the initiative of the president, overturned the results of the presidential election announced by the nation's Electoral Commission. The results had previously proclaimed the president to be the loser of the runoff, but the Constitutional Council declared the incumbent, Laurent Gbagbo, the official winner. ${ }^{99}$ As a consequence, the country experienced a legal and political crisis with two men claiming to be president: one proclaimed by the Electoral Commission, the other declared by the Constitutional Council. ${ }^{100}$

Yet in the DRC, under article 3 of the Bill on the Functioning of the Constitutional Court, "[t]he Chairman of the Constitutional Court should be elected by his peers of the court for a period of three years renewable once. He is vested by the ordinance of the president of the Republic." Even though the chairman will be chosen by his peers, the risk of "politicization" is still present, since the decision of the court is taken by a simple majority of its voting members, and two out of three members of the Constitutional Court are selected by those in Parliament and government. ${ }^{101}$

Thirdly, some provisions of the 2011 Amendment Law ${ }^{102}$ and the COCJ,103 specifically those placing the magistrat $d u$ parquet under the authority of the minister of justice, should be revised. The revision should consider cutting "the umbilical cord" linking the magistrat du parquet with the minister of justice. In so doing, the magistrat du parquet would be more autonomous as a judicial officer rather than being considered a functionary of the state who

96 Ibid. See also: The Carter Center "DRC presidential election results lack credibility" (10 December 2011), available at: <http://www.cartercenter.org/news/pr/drc-121011.html> (last accessed 9 May 2012). Ibid.

98 Ibid.

99 UN Office for the Co-ordination of Humanitarian Affairs "Côte d'Ivoire post-electoral crisis" (humanitarian report no 1, 28 December 2010), available at: <http://www.geceao. org/sites/default/files/Sitrep_CIV_28dec2010.pdf> (last accessed 9 May 2012).

100 Ibid.

1012006 Constitution, art 158(1).

102 Art 149.

103 COCJ, art 10. 
may receive an injunction from the minister of justice to initiate or dismiss any criminal investigation. ${ }^{104}$ Accordingly, the Congolese legislator may, for instance, refer to the Egyptian experience. The Egyptian Law No 46/1972, as amended in June 2006, introduced the innovation of placing the public prosecutors under the supervision of their hierarchical chief. ${ }^{105}$ Before that amendment, Egyptian public prosecutors were also under the supervision of the minister of justice. ${ }^{106}$

In the same way, it is suggested that the magistrat du parquet be placed under the supervision of both his hierarchical chief (for instance, the general prosecutor of the Republic) and the CSM. This is workable as the CSM is constitutionally the ruling authority of the judiciary, and the general prosecutor of the Republic is the hierarchical superior of all public prosecutors.

Finally, with the collaboration of the CSM, a specific scale should be set to ensure that magistrates' salary reflects the dignity of the profession and the burden of their responsibilities. The monthly salary for Congolese judges currently ranges from 100 to 200 US dollars. ${ }^{107}$ One may attempt to argue that such an insignificant salary results from the bad economic situation of the country, since other functionaries of the state receive relatively the same salary. However, such an allegation is only partially true. This is because the remuneration scheme for parliamentarians and ministers as published by the Ligue Congolaise de Lutte Contre la Corruption [Congolese Network Against Corruption] reveals that, even in the context of the current economic crisis, the monthly salary for those sitting in the Congolese Parliament and government ranges from 6,000 - 7,000 US dollars. ${ }^{108}$ From this revelation, and considering the burden of responsibilities weighing on magistrates, it is suggested that magistrates be granted equivalent remuneration to that of ministers and parliamentarians.

As Dr Yav Katshung revealed, unpaid salaries combined with poor working conditions expose Congolese magistrates to the potential risk of corruption and related offences. ${ }^{109}$ Adequate payment for judicial officers will safeguard

104 Id, art 12: "The general prosecutor of the Republic may, on the order of the minister of justice, initiate or continue any investigation of an offence."

105 N Bernard-Maugiron "Vers une plus grande indépendance du pouvoir judiciaire en Egype?" ["Towards greater independence for the judiciary in Egypt?"] (2007) 59/1 Revue Internationale de Droit Comparé [International Comparative Legal Review] 83.

106 Ibid.

107 W Djamba "RDC: Quelle réforme du système judiciaire pour l'établissement d'un état de droit?" ["DRC: What reform of the judicial system would establish the rule of law?"] (21 February 2007) Pambazuka News, available at: <http://pambazuka.org/fr/category/ comment/39956> (last accessed 6 June 2011).

108 Congolese Network Against Corruption "Press release no 038/LICOCO/SG/2011" at 4-11, available at: <http://www.atol.be/bib/opac_css/doc_num.php?explnum_id=1556> (last accessed 14 May 2012).

109 J Yav Katshung "Oui à l'indépendance du pouvoir judiciaire en RDC. Mais avec quels opérateurs judiciaires?" ["Yes to the independence of the judiciary in the DRC. But with which judicial actors?"] (25 June 2008) La Conscience, available at: <http://www. 
the individual independence of magistrates vis-à-vis the persons (or institutions) to whom their decisions must be applied.

\section{CONCLUSION}

Six years after the promulgation of the constitution of the "Third Republic" and the Law on the Status of Magistrates, the independence of the judiciary in the DRC is still in question. An overall assessment of judicial independence in the DRC today reveals that newly adopted legislation on the status of magistrates and on the organization and functioning of the CSM has brought about a kind of "revolution" in the justice system, since the legislation has increased the CSM's competence and reduced to some degree the traditional control of the executive over the judiciary, constituting an important step toward judicial independence. Despite the introduction of these innovations, however, the legislation does not offer absolute independence to the judiciary, since there are still some improvements that need to be made.

contd

laconscience.com/Oui-a-1-independance-du-Pouvoir-Judiciaire-en-RDC-Mais-avec-quelsOperateurs-Judiciaires.html> (last accessed 9 May 2012). 